\title{
Ladrang Sobrang Laras Slendro Patet Nem
}

\author{
Teguh $^{1}$ \\ Jurusan Karawitan, Fakultas Seni Pertunjukan, Institut Seni Indonesia Yogyakarta
}

\begin{abstract}
Ladrang Sobrang of Laras Slendro Patet Nem. This article aims to find out the structure of the Ladrang Sobrang composition and the way the composer determines how to play it. Sobrang is one of the Javanese gamelan compositions found in Surakarta style. This composition is chategorized into gending alit, in the form of ladrang, performed in Slendro gamelan and mode Patet Nem. Furthermore, the composition is classified as ladrang ageng because it consists of four cengkoks or four gongs. None of these four cengkoks are followed by vocals. It can be understood that this composition mainly focuses on the play of ricikan instruments. Data is obtained through observations on the presentations of this composition and interviews with musicians. After analyzing the tone strength and musical work, it can be concluded that Ladrang Sobrang is classified as a complicated and difficult composition because it consists of two patets, namely patet sanga and manyura, has a special drum performance or pamijen, and has beating pattern on kenong goyang.
\end{abstract}

Keywords: Ladrang Sobrang; Surakarta gamelan; gamelan composition

\begin{abstract}
ABSTRAK
Artikel ini bertujuan untuk mengetahui struktur gending Ladrang Sobrang dan cara pengrawit dalam menentukan garap untuk memainkannya. Sobrang adalah salah satu nama gending yang terdapat pada karawitan gaya Surakarta. Gending ini dikelompokkan pada gending alit, berbentuk ladrang, berlaras slendro, dan berpatet nem. Gending ini tergolong jenis ladrang ageng, karena terdiri dari empat cengkok atau empat gong-an. Dari keempat cengkok ini tidak ada satupun yang diikuti vokal. Hal ini dapat dipahami bahwa gending ini mengutamakan permainan instrumen ricikan. Data diperoleh melalui pengamatan pada penyajian gending ini dan wawancara dengan para ahli karawitan. Setelah dilakukan analisis pada kekuatan nada dan analisis garap, dapat disimpulkan bahwa Ladrang Sobrang tergolong gending yang rumit dan sulit karena terdiri dari dua patet yaitu patet sanga dan manyura, mempunyai permainan kendang khusus atau pamijen, dan mempunyai pola tabuhan kenong goyang.
\end{abstract}

Kata kunci: Ladrang Sobrang; karawitan Surakarta; balungan gending

\section{Pendahuluan}

Sobrang adalah salah satu gending laras slendro patet nem (Mloyowidodo, 1973) dan berbentuk ladrang ageng yang terdapat pada karawitan gaya Surakarta. Disebut ladrang ageng karena ladrang ini terdiri dari empat cengkok atau empat gongan (Prajapangrawit, 1990). Cengkok atau gong-an pertama tonika seleh gong 1 (barang), cengkok kedua tonika seleh gong 5 ( $m a$ ), cengkok ketiga tonika seleh gong6 (nem) dan cengkok yang terakhir atau keempat tonika seleh gong 6 (nem). Meskipun Ladrang Sobrang terdiri dari empat cengkok atau empat gongan, namun tidak ada cengkok yang dikhususkan sebagai umpak dan ngelik sebagaimana gending bentuk ladrang lainnya. Fakta ini menunjukkan bahwa penyajian Ladrang Sobrang dari cengkok pertama sampai dengan cengkok keempat secara berurutan, sehingga tidak ada cengkok yang harus disajikan berulang-ulang. Gending ini memiliki

Alamat korespondensi: Jurusan Karawitan, Fakultas Seni Pertunjukan, ISI Yogyakarta. Jln. Parangtritis KM. 6,5 Sewon, Yogyakarta. E-mail: teguh@isi.ac.id. HP. +6282242586003. 
garap khusus seperti halnya garap kendang pamijen dalam karawitan gaya Yogyakarta (Sri Atmojo, 2010).

Ladrang Sobrang baik dalam sajian klenéngan maupun sebagai iringan wayang kulit, tidak pernah dimainkan menggunakan vokal (gerongan). Walaupun dalam dunia karawitan kebebasan mengolah atau menggarap sebuah gending terbuka lebar termasuk membuat vokal (gerongan), namun demikian tidak ada satupun pengrawit yang mempunyai ide atau gagasan untuk membuat gerongan untuk gending ini. Hal ini berarti bahwa Ladrang Sobrang lebih mengutamakan garap atau permainan instrument terutama rebab dan gender barung. Di kalangan para pengrawit, gending ini terkenal jenis gending yang sangat sulit garapnya. K.R.R.A. Saptodiningrat mengatakan sebagai berikut:

Sanadyan Sobrang kuwi bentuke mung sak ladrang, nanging ora gampang garape, mligine garap ricikan ngarep kaya to rebab lan gender, jalaran ladrang iki rong pathet dadi siji yaiku pathet sanga lan manyura. (Wawancara, 25 Pebruari 2017 di Keraton Surakarta).

[walaupun Sobrang itu bentuknya ladrang tetapi garapnya tidak mudah, terutama garap ricikan depan seperti rebab dan gender, karena ladrang ini terdiri dari dua pathet yaitu sanga dan manyura]

Penulis juga mendapatkan penjelasan dari seorang pemain rebab (pengrebab) yakni Broto Adi Nagoro yang mengatakan sebagai berikut;

Ngrebabi Ladrang Sobrang kuwi kudu ngerti endi sing kudu digarap sanga lan endi sing kudu digarap manyura, amarga rebab kuwi rak dadi panutane garap ricikan liyane, kalebu uga garap sindhenane. Akeh pesindhen sing ora iso nyindheni merga garape rebab ora jejeg. (Wawancara, 3 Maret 2017 di Baluwarti Surakarta).

[Ngrebabi Ladrang Sobrang harus tahu mana yang digarap sanga dan yang digarap manyura, karena rebab itu menjadi panutan atau kiblat garap ricikan yang lain, termasuk garap sindhen. Banyak pesindhen yang tidak bisa nyindheni dengan baik karena garap rebab yang tidak jelas]

Berdasarkan penjelasan kedua pengrawit di atas dapat diketahui bahwa Sobrang walaupun hanya berbentuk ladrang, tetapi terkenal sebagai gending yang tingkat kerumitan garap-nya sangat tinggi, karena Ladrang Sobrang berisi dua patet yaitu patet sanga dan manyura. Penelitian Prasetya menunjukkan bahwa terdapat sekat pintu antara ruang bunyi patet sanga dan manyura. Apabila akan memainkan dua gending berbeda patet, patet sanga dan manyura secara beruntun tidak dapat dilakukan dengan cepat dan tiba-tiba, tetapi dibutuhkan melodi grambyangan gender sebagai pembuka pintu patet. Hal ini akan berbeda misalnya perpindahan dari patet nem ke manyura atau sebaliknya, cukup dilakukan melodi thinthingan gender karena tidak terdapat sekat yang kuat antara patet nem dan manyura (Prasetya, 2012).

Kesulitan memainkan gending Ladrang Sobrang terutama dalam garap ricikan depan yaitu gender dan rebab. Kualitas atau kekuatan penggender memberikan kehidupan atau rasa pada sebuah pertunjukan, bukan semata-mata terletak pada keterampilan teknis permainan melodinya, tetapi pada ketepatan dalam memilih karakter musikalnya berkaitan dengan kebutuhan (Sukistono, 2014).

Rebab termasuk salah satu ricikan spesial dalam karawitan (Setiawan, 2015). Seorang pengrebab harus memahami berbagai unsur karawitan dan prinsip menabuh setiap waditra agar terjalin keharmonisan sajian karawitan (Saepudin, 2015a). Wilayah nada rebab mencakup luas wilayah semua gendhing sehingga alur lagu rebab memberi petunjuk jelas tentang jalan alur lagu gendhing (Suwandi Putri, Fikroturrofiah \& Ardhi Saputri, 2015). Segala yang berurusan dengan lagu dan patet pada sajian gending, rebablah yang berkuasa atau yang memimpin, dalam hal ini termasuk menentukan garap gending(Martopangrawit, 1975). Oleh karena rumitnya garap, maka fakta menunjukkan Ladrang Sobrang jarang sekali disajikan atau ditabuh oleh grup-grup karawitan pemula dan atau yang tingkat keterampilannya dalam menggarap gending masih belum "baik", sehingga intensitas penyajian Ladrang Sobrang dapat 
dikatakan sangat jarang, hanya grup karawitan yang tingkat kemampuan garap-nya tinggi yang sering menyajikan.

Ladrang Sobrang terdiri dari dua patet yaitu patet sanga dan manyura, tetapi cengkok atau gong-an yang termasuk sanga dan manyura tidak pernah ditulis atau tanpa keterangan, sehingga garap-nya mutlak tergantung penggarap-nya atau pengrawitnya. Maka, seorang pengrawit membutuhkan tafsir waktu, tafsir pathet, tafsir garap, dan juga tafsir gending (Purwanto, 2013). Oleh karena itu, garap musikal karawitan bergantung faktor kreativitas dari para seniman dalam rangka untuk memenuhi kebutuhannya (Sugimin, 2013). Pada gilirannya, dengan kebiasaan menafsir sebagai kerangka yang melahirkan dan memberi bentuk kepada persepsi, representasi, dan tindakan seorang pengrawit (Budi Prasetya, Haryono, \& Simatupang, 2011).

Ladrang Sobrang terdapat rebaban baik laras slendro nem maupun laras pelog patet barang (Djumadi, 1975). Menurut dugaan penulis, Ladrang Sobrang Laras Slendro Patet nem ini memiliki sesuatu yang misteri untuk dicari jawabannya. Kolaborasi garap ricikan yang satu dengan ricikan lainnya akan menimbulkan harmoni dalam sebuah sajian gending, sehingga ketepatan pemilihan patet menjadi sangat penting, begitu pula sebaliknya tanpa alasan yang mendasar sajian sebuah gending menjadi hambar atau bahkan tidak berkualitas, cebleh, sangli, ora mungguh dan seterusnya. Oleh karena itu, tujuan penulisan ini untuk mengetahui struktur Ladrang Sobrang laras slendro patet nem serta cara pengrawit dalam menentukan garap.

Penelitian ini dilakukan dengan cara mengamati penyajian Ladrang Sobrang laras slendro patet nem dalam sajian karawitan/klenèngan. Garap Ladrang Sobrang ini tentu berkaitan dengan garap ricikan yang lain seperti rebab, gender barung, bonang barung, siter, suling, gambang, dan vokal (sindhen dan gerong). Mengapa demikian?, karena sifat musik gamelan itu adalah musik gotong royong, artinya garapan ricikan satu dengan ricikan yang lain saling mengisi, saling merespon, saling menginspirasi. Di sini terjadi komunikasi hasil kerjasama antar unsur yang ada, bersifat kolektif, saling mendukung untuk memberi tempat berekspresi sesuai dengan hak dan kewajibannya (Setyawan, 2017). Setiap pemain bekerja sama untuk memainkan gamelan dengan pemain kendang sebagai pemimpinnya (Osada, 2015). Dari perpaduan garapan ricikan itulah maka kemudian akan membangun sajian gending yang harmoni, regu, regeng, nges dan nyawiji serta mungguh. Musik merupakan stimulus universal yang sangat berpotensi menginduksi suasana hati (Finahari \& Soebiyakto, 2017).

\section{Struktur Gending Ladrang Sobrang}

Saepudin menyatakan tentang gending sebagai berikut:

Gending bersifat abstrak, dapat dirasakan melalui indera pendengaran tetapi tidak dapat dilihat melalui indera mata. Gending dapat dirasakan jika telah terjadi jalinan komunikasi sekaligus perpaduan yang harmonis antara setiap komponen gamelan yang ada dalam satu waktu penyajian. Perpaduan harmonis terwujud ketika komunikasi masing-masing waditra yang dimainkan oleh pangrawit terjalin dengan baik. Komunikasi tidak hanya bersifat memberi informasi atau tanda dari seorang pangrawit ke pangrawit lainnya, tetapi saling memberi dan menerima apa-apa yang dikomunikasikan dalam permainan gamelan melalui waditra yang dimainkannya (Saepudin, 2012).

Pradjapangrawit menjelaskan bahwa gending ladrang dikelompokkan menjadi tiga macam yaitu, Ladrang Ageng, Ladrang Tengahan, dan Ladrang Alit

Ingkang winastan ladrangan agêng inggih punika ladrangan ingkang céngkokipun sakêdhik-kêdhikipun sêkawan, Ingkang winastan ladrangan têngahan inggih punika ladrangan ingkang anggadhahi sakêdhiksakêdhikipun kalih. Ingkang winastan ladrangan alit inggih punika ingkang namug céngkok satunggal (Pradjapangrawit, 1990: 73).

[Yang dimaksud ladrangan ageng adalah ladrangan yang terdiri dari sediktnya 4 
cengkok. Yang dimaksud ladrangan tengahan apabila terdiri sedikitnya 2 cengkok. Yang dimaksud ladrangan yang hanya terdiri dari 1 cengkok]

Merujuk pernyataan Pradjapangrawit tersebut, dapat dipahami bahwa Ladrang Sobrang adalah salah satu gending termasuk jenis ladrang ageng, karena terdiri dari empat gong-an atau empat cengkok.

Ladrang Sobrang memiliki struktur tabuhan ricikan struktural yang terdiri dari kempyang, kethuk, kenong, kempul dan gong. Pola tabuhan kethuk berfungsi untuk menandai satu pengkalimatan lagu, pola tabuhan-nya terletak pada sabetan kedua dalam setiap gatra. Jadi, setiap dua tabuhan kethuk menandai satu kalimat lagu. Sedangkan setiap kalimat lagu ditandai oleh tabuhan kenong. Dengan demikian, letak tabuhan kenong dapat dianalogikan sebagai titik yang menandai selesainya sebuah kalimat lagu dengan bentuk dan kesan yang utuh. Selanjutnya titik akhir dari susunan kalimat lagu gending ditandai dengan tabuhan gong, pola tabuhan tersebut sekaligus menandai ukuran bentuk gending. Bentuk gending secara umum ditandai dari gong ke gong (Saepudin, 2015b).

Berikut adalah struktur Ladrang Sobrang berdasarkan pola tabuhan ricikan strukturalnya:

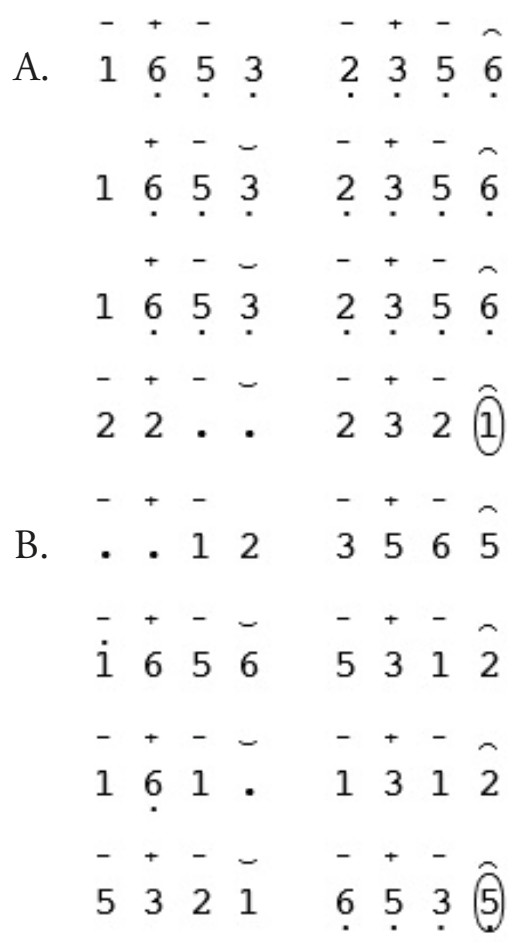

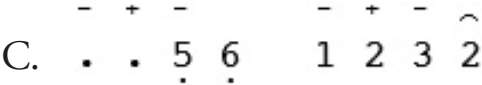

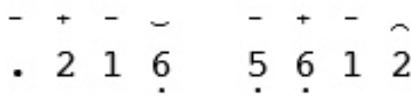

$$
\begin{aligned}
& \text { - + - + - } \\
& \text {.. } 16 \text {.. } 56 \\
& \begin{array}{lllllll}
\bar{i} & + & - & - & - & + & \bar{i}
\end{array} \\
& \text { D. . . } 665 \hat{6} \\
& \text { i }+\bar{i} 6 \bar{i} \quad-+-\bar{c} \\
& \text {. } 356 \text { i } 653
\end{aligned}
$$

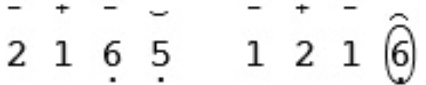

Keterangan: : kempyang; : kethuk; : kenong; :kempul; : gong

Berdasarkan notasi di atas, struktur pola tabuhan Ladrang Sobrang dalam satu gong-an terdiri atas 4 tabuhan atau satuan kenong (kenongan). Setiap satuan kenong terdiri atas 8 sabetan balungan atau 2 gatra. Setiap gatra terdapat 2 tabuhan kempyang dan 1 tabuhan kethuk. Tabuhan kempyang pada sabetan pertama dan ketiga setiap gatra. Tabuhan kethuk terletak pada sabetan kedua setiap gatra. Tabuhan kempul terdapat pada séléh gatra ketiga, lima dan ketujuh. Tabuhan gong tepat pada seleh gatra kedelapan. Jadi dalam satu gong-an (satuan gong) terdiri atas 4 X 8, atau 32 sabetan balungan. Gatra adalah satuan atau unit terkecil dari gending (komposisi) karawitan Jawa yang terdiri dari empat sabetan balungan (Supanggah, 2009: 77).

\section{Analisis Padhang-Ulihan berdasarkan Cengkok atau Gong-an}

Suatu gending atau lagu keberadaannya ditunjang oleh balungan gending atau kerangka lagu yang secara umum bersifat filosofis. Balungan gending merupakan suatu bunyi nada dasar atau inti komposisi suatu gending yang keberadaannya hanya ada pada saat gending tersebut dipagelarkan(Diah $\mathrm{K}, 2010)$. Gending di dalamnya terdiri dari irama, laya, laras, dan dinamika (Widodo, Ganap, 2017). Setiap gending dibangun oleh unsur terkecil (nada) 
yang membangun sebuah struktur baru. Struktur baru tersebut selanjutnya saling mengikat, saling berelasi, dan membentuk struktur yang lebih besar, sehingga terbentuk struktur akhir yang lazim disebut dengan gending (Martopangrawit, 1975).

Sebuah gending mirip dengan sebuah kalimat. Apabila sebuah kalimat tersusun oleh frasa, maka gending tersusun oleh frasa lagu berupa pertanyaan yang dikenal dengan istilah padhang (p) dan frasa lagu jawaban yang dikenal dengan istilah ulihan (u) (Prasetya, 2013). Dengan demikian setiap gending tersusun oleh frasa-frasa padhang-ulihan. Frasa padhang tidak selalu sama jumlahnya dengan frase ulihan, bahkan lebih sering frase padhang lebih banyak dari frase ulihan-nya, seperti halnya Ladrang Sobrang ini.

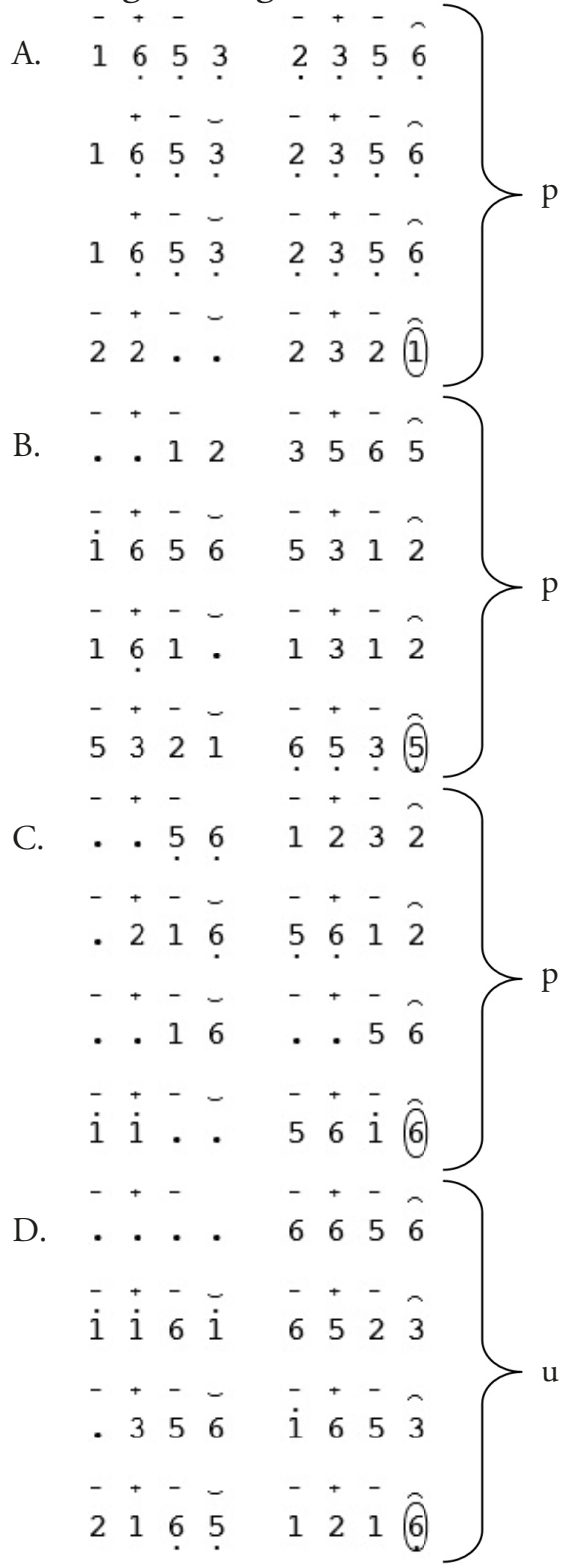

Keterangan: $\mathrm{P}=$ padhang; $\mathrm{u}=$ ulihan
Walau Ladrang Sobrang terdiri dari empat gong-an atau empat cengkok, namun tidak ada umpak dan ngelik. Struktur padhang-ulihan berdasar pada setiap cengkok atau gong-an, yaitu bagian A, B dan C padhang (p), bagian D sebagai ulihan (u).

\section{Analisis Patet Berdasar Seleb Gatra dan Nada Gong}

Matrik 1

\begin{tabular}{|c|c|c|c|c|c|c|c|c|}
\hline No & $\mathrm{A}$ & B & C & $\mathrm{D}$ & E & F & G & $\mathrm{H}$ \\
\hline 1 & 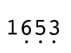 & ب & 1653 & 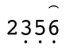 & 1653 & ط & 22. & $232 \hat{1}$ \\
\hline 2 & $\ldots 12$ & 3565 & 1656 & 5312 & $161^{1}$ & 1312 & 5321 & $653(5)$ \\
\hline 3 & . 56 & 1232 & .216 & 5612 & .216 & $\ldots 56$ & ii.. & $56 i \hat{)}$ \\
\hline 4 & ..6 & 6656 & iiri & 6523 & .356 & $i 653$ & 2165 & $121 \hat{(6)}$ \\
\hline
\end{tabular}

Cengkok atau gong-an A (pertama)

1A, 1B, 1C, 1D, 1E dan 1F adalah merupakan lagu yang berpatet nem, karena seleh setiap gatra merupakan nada kuat dalam patet nem. Sedangkan pada $1 \mathrm{G}$ dan $1 \mathrm{H}$ bisa di-garap dua kemungkinan yaitu patet manyura dan patet sanga. Susunan balungan $1 \mathrm{G}$ dan $1 \mathrm{H}$ seperti itu sebenarnya sering dijumpai pada patet manyura tetapi setelah masuk bagian dari cengkok $A$, tidak bisa tumbuh dan berkembang patet manyura itu. Oleh karena itu ada satu kemungkinan lagi yaitu di-garap dengan patet sanga. Dengan demikian maka $1 \mathrm{G}$ dan $1 \mathrm{H}$ ditetapkan sebagai awal masuknya patet sanga alasan yang mendasar adalah kalimat lagu yang mengikuti atau setelah $1 \mathrm{G}$ dan $1 \mathrm{H}$.

\section{Cengkok atau gong-an B (kedua)}

Penentu masuknya patet sanga adalah 2A dan 2B, mengapa kedua gatra ini disebut sebagai penentu, karena séléh $2 \mathrm{~A}$ adalah kempyung atas dan 2B sebagai nada dasar atau dong patet sanga. Pada cengkok atau gong-an ini rasa patet sanga semakin kuat karena didukung berturut-turut dari $2 \mathrm{C}$, walaupun $2 \mathrm{C}$ séléh nada pelengkap tetapi berada pada kalimat padhang dan dikuatkan 2D merupakan kempyung atas, 2E adalah kempyung bawah dan $2 \mathrm{~F}$ kempyung atas, dan patet sanga sangat mantap karena cengkok atau gong-an $\mathrm{B}$ 
ditutup dengan kekuatan nada dong patet sanga yakni nada 5 (lima) ageng. Dengan demikian cengkok atau gong-an B adalah merupakan patet sanga.

\section{Cengkok atau gong-an C (ketiga)}

Cengkok ini patet sanga masih sangat terasa walaupun $3 \mathrm{~A}$ seleh nada pelengkap tetapi merupakan seleh ringan, yaitu berada dalam kalimat lagu padhang dan diikuti 3B merupakan kempyung atas. Hal demikian berulang pada 3C dan 3D yakni nada pelengkap dan kempyung atas patet sanga. Jika merujuk tulisan Supanggah dalam Bothekan II 3E dan 3F adalah jenis balungan gantungan (Supanggah, 2009: 104). Dalam hal ini balungan gantung 6 (nem) alit, nada 6 (nem) dalam laras slendro patet sanga adalah nada pelengkap yang kedudukannya tidak terlalu kuat, apalagi ditempatkan pada seleh ringan yaitu tepat seleh kenongan ketiga. Khusus untuk $3 \mathrm{G}$ dan $3 \mathrm{H}$ atau tepat pada kenong keempat bersamaan dengan gong, dipahami sebagai susunan balungan yang keluar dari patet sanga dan selanjutnya merupakan awal masuk ke patet manyura. Saat penulis berbincang-bincang dengan nara sumber, ada yang beranggapan $3 \mathrm{G}$ dan $3 \mathrm{H}$ masih termasuk dalam patet sanga, alasannya adalah bahwa susunan balungan itu merupakan balungan gantung dari 3E dan $3 \mathrm{~F}$, agar supaya masih terasa dalam suasana patet sanga maka di-garapminir. Tetapi nara sumber yang lain punya argumen bahwa $3 \mathrm{G}$ dan $3 \mathrm{H}$ itu adalah dalam wilayah patet manyura.

\section{Cengkok atau gong-an D (keempat)}

Mengapa kemudian pada 3G dan 3H dianggap sebagai awal masuk patet manyura, karena diikuti dengan susunan balungan $4 \mathrm{~A}$ dan $4 \mathrm{~B}$ sebagai nada dong dari patet manyura. Selanjutnya pada $4 \mathrm{C}$ adalah nada pelengkap yang berfungsi sebagai jembatan menuju ke 4D yaitu kempyung atas, rasa patet manyura terus berlanjut sampai dengan 4E dan 4F. Jika diperhatikan secara seksama susunan balungan 4A sampai $4 \mathrm{~F}$ adalah merupakan teba nada-nada pada wilayah slendro patet manyura. Rasa nuansa slendro patet nem baru terasa pada $4 \mathrm{G}$ dan $4 \mathrm{H}$. Uraian analisis patet pada Ladrang Sobrang seperti tersebut di atas, dapat disimpulkan bahwa patet yang terdapat pada Ladrang Sobrang adalah campuran patet sanga dan manyura.

\section{Analisis Berdasarkan Garap}

\begin{tabular}{|c|c|c|c|c|c|c|c|c|}
\hline No & $\mathrm{A}$ & B & $\mathrm{C}$ & $\mathrm{D}$ & $\bar{E}$ & $\bar{F}$ & $\bar{G}$ & $\overline{\mathrm{H}}$ \\
\hline 1 & 1653 & $235 \overline{6}$ & 1653 & $235 \hat{6}$ & 1653 & $235 \overline{6}$ & 22. & $232(1)$ \\
\hline 2 & $\ldots 12$ & $356 \hat{5}$ & i656 & $531 \hat{2}$ & 161. & $131 \hat{2}$ & 5321 & $653(5)$ \\
\hline 3 & . 56 & $123 \hat{2}$ & .216 & 5612 & .216 & $\ldots 56$ & ii.. & $56 \mathrm{i}(\hat{6}$ \\
\hline 4 & $\ldots 6$ & 6656 & iiri & $652 \hat{3}$ & .356 & i653 & $216 \underset{ }{2}$ & $121(\hat{6})$ \\
\hline
\end{tabular}

\section{Cengkok atau gong-an A (pertama)}

$1 \mathrm{~A}, 1 \mathrm{~B}, 1 \mathrm{C}, 1 \mathrm{D}, 1 \mathrm{E}$ dan $1 \mathrm{~F}$ bisa digarap patet nem dan bisa juga patet manyura. Broto Adi Nagoro menjelaskan:

Nék balungan gending sabên sak kenong mung ana 2 gatra, kaya Ladrang Sobrang kui kanggoné pêngrêbab angél mbédakaké endi sing digarap nem lan endi sing kudu digarap manyura. Tumrapé tatajari utawa posisi jari gatra siji nganti tekan enem nganggo tatajari siji manyura (Wawancara, 2 Juli 2017 di Keraton Surakarta).

Jika balungan gending setiap satu kenongan hanya 2 gatra, seperti Ladrang Sobrang itu, pengrebab kesulitan untuk membedakan mana yang digarap nem dan manyura. Untuk tatajari atau posisi jari mulai dari gatra pertama sampai gatra ke 6 menggunakan tatajari slendro manyura. $1 \mathrm{G}$ dan $1 \mathrm{H}$ merupakan awal garapan slendro sanga, alasannya karena susunan balungan seperti itu banyak dijumpai pada patet sanga, maka kemudian digarap dengan cengkok Putut-gelut. Supaya patet sanga menjadi kuat harus didukung garap gender barung, artinya gender barung juga memainkan cengkok putut gelut patet sanga.

\section{Cengkok atau gong-an B (kedua)}

Cengkok atau gong-an Bmulai dari 2A sampai $2 \mathrm{H}$ merupakan patet sanga. Oleh karena itu maka posisi atau tatajari rebabannya juga menggunakan tatajari patet sanga, yaitu posisi satu jari telunjuk pada nada 1 (barang), posisi kedua telunjuk pada nada 2 (jangga) dan posisi ketiga jari telunjuk pada 
nada 5 (lima) dan jari yang lain, yakni jari tengah, manis dan kelingking menyesuaikan jari telunjuk. Balungan gending yang perlu dibahas garapnya dalam cengkok atau gong-an B (kedua) ini hanya 2A dan 2B saja. Saptodiningrat mengatakan sebagai berikut:

Gong-an sing ping pindho kenongan sepisan kui iso digarap minir, nék tembungé iso kuwi têgêséora kudu, jalaran ana pengrêbab sing ora nggarap minir panggonan kuwi (Wawancara tanggal 12 Juli 2017 di Keraton Surakarta).

[Gong-an yang kedua kenong pertama itu bisa digarap minir, kalau kemudian ada kata bisa artinya pada balungan itu tidak harus minir, karena juga ada pengrebab yang tidak menggarap minir]

\section{Cengkok atau gong-an C (ketiga)}

Cengkok atau gong-an $\mathrm{C}$ dari $3 \mathrm{~A}$ sampai $3 \mathrm{H}$ masih berpatet sanga. Hampir semua digarap minir baik minirwutuh maupun hanya satu gatra atau separo saja. Yang digarap minirwutuh dua gatra adalah 3A, 3B, 3C dan 3D. Sedangkan yang digarap minir separo atau satu gatra adalah $3 \mathrm{~F}$ dan $3 \mathrm{H}$. Garap rebab adalah, khusus $3 \mathrm{G}$ dan $3 \mathrm{H}$ sebenarnya bisa digarap dua versi yaitu patetsanga dan patet manyura, jika digarap patet manyura artinya bahwa $3 \mathrm{G}$ dan $3 \mathrm{H}$ merupakan awal masuk patet manyura atau keluar dari patet sanga.

Alasan mengapa $3 \mathrm{G}$ dan $3 \mathrm{H}$ digarap manyura karena susunan balungan yang mengikuti yakni $4 \mathrm{~A}$ dan 4B. Kasus ini kiranya sama dengan kasus pada cengkok A, 1G dan $1 \mathrm{H}$ merupakan awal masuk patet sanga karena susunan nada yang atau melodi balungan yang mengikuti. Apabila 3G dan $3 \mathrm{H}$ patet manyura maka posisi atau tatajari adalah; posisi pertama jari telunjuk pada nada 1 (barang), posisi kedua jari telunjuk pada nada 3 (dhadha) dan posisi ketiga jari telunjuk pada nada 6 (nem) alit, jari yang lainnya menyesuaikan jari telunjuk. Nada yang bisa digarap minir adalah nada 3 (dhadha) dan 6 (nem) alit. Berkaitan dengan garap minir KRT Broto Adi Nagoro mengatakan sebagai berikut:

Garap minir tumrap tabuhan rebab kui ana loro yaiku minir baku karo minir pasrèn. Minir baku kuwi balungan sing kudu digarap minir, nék minir pasrèn kuwi balungan sing ora kudu digarap minir (Wawancara, $24 \mathrm{Mei}$ 2017 di Keraton Surakarta).

[Garap minir untuk tabuhan rebab pada dasarnya ada dua yaitu minir baku dan minir pasren. Minir baku bilamana balungannya harus digarap minir, sedangkan minir pasren yaitu apabila balungannya tidak harus digarap minir]

Keterangan Broto Adi Nagoro seperti tersebut di atas, jika garap minir di aplikasikan pada garap rebab Ladrang Sobrang adalah sebagai berikut: $2 \mathrm{~A}$ dan $2 \mathrm{~B}, 3 \mathrm{~F}$ dan $3 \mathrm{H}$ garapan minir pasren, alasannya balungan seperti itu tidak harus digarap minir, artinya bisa digarap yang lain yang tidak minir. Sedangkan minir baku diaplikasikan pada balungan 3A, 3B, 3C dan 3D. Garap minir bisa dilakukan apabila berada pada seleh (kenong dan gong atau tergantung bentuk gendingnya). Nada laras slendro patet sanga yang bisa digarap minir yaitu; 2 (jangga), 5 (lima) dan 6 (nem).

\section{Cengkok atau gong-an D (keempat)}

Apabila 3G dan 3H tidak digarap manyura atau masih patet sanga, maka $4 \mathrm{~A}$ dan $4 \mathrm{~B}$ adalah sebagai awal masuk ke patet manyura, walaupun 4A dan 4B merupakan awal masuk patet manyura, susunan balungan seperti itu bisa di-garap minir, dengan digarap minir maka menjadi nyambung dengan garapan sebelumnya atau pada cengkok ketiga yang masih berpatet sanga.

Alasan mengapa 4A dan 4B merupakan patet manyura, karena susunan balungan berikutnya yaitu 4C, 4D, 4E dan 4F adalah susunan balungan yang nada-nadanya termasuk dalam wilayah patet manyura. Seleh gatra pada pada 4C sampai 4F adalah nada tonika patet manyura. $4 \mathrm{G}$ dan $4 \mathrm{H}$ adalah merupakan susunan balungan patet nem, karena 4G merupakan nada tonika patet nem dan diikuti dengan nada tonika patet nem.

\section{Analisis Garap Kendang}

Di bawah ini adalah kendang-an Ladrang Sobrang hasil transkrip dari rekaman dengan pengendang KRT. Radyo Adi Nagoro. 
A.

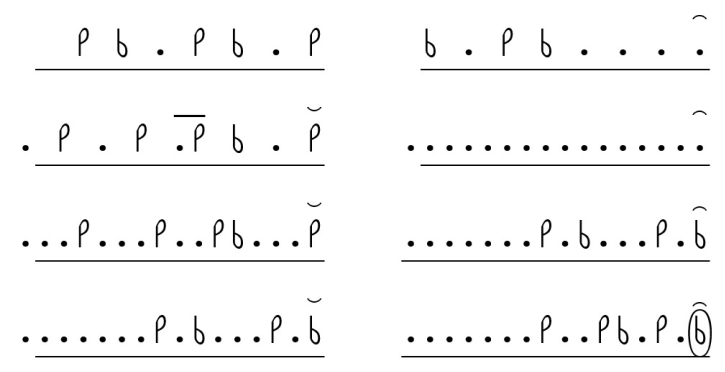

Kendang-an A digunakan untuk peralihan dari irama tanggung ke irama dadi atau dados.

B.

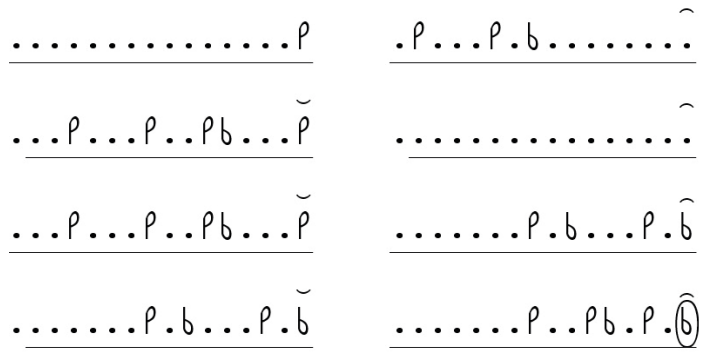

C.

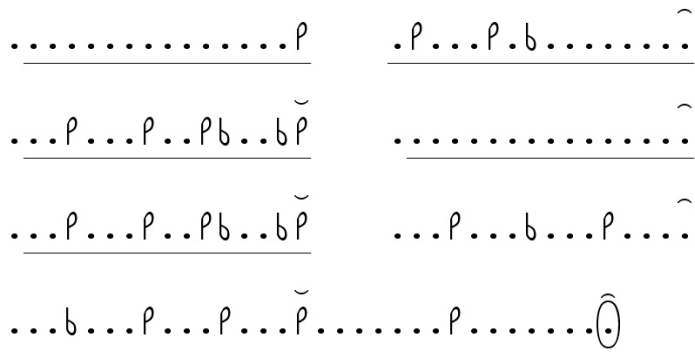

Keterangan: $P$ : thung; $b$ : dhah; : kenong; : kempul; $\cap$ : gong

Kendang-an A digunakan untuk peralihan, $\mathrm{B}$ dimainkan berulang-ulang, dan $\mathrm{C}$ digunakan khusus untuk penutup atau suwuk.

\section{Analisis Garap Tabuhan Kenong}

Dalam dunia karawitan gaya Surakarta, Ladrang Sobrang dikenal sebagai sebuah gending yang mempunyai teknik tabuhan kenong spesifik atau dalam kalangan pengrawit disebut tabuhan pamijen yaitu yang lazim disebut kenong goyang. Estetika (keindahan) penyajian/menabuh kenong tidak hanya terletak pada ketepatan pukulan kenong, melainkan terletak pada tafsir waktu, tafsir pathet, tafsir garap, dan juga tafsir gending (Purwanto, 2013). Berkaitan dengan tabuhan kenong goyang, berdasarkan atas pengamalan masing-masing dua nara sumber penelitian ini berbeda pendapat yaitu K.R.A.A Saptodiningrat mengatakan sebagai berikut;

Ladrang Sobrang sléndro nem kuwi, nék kendhangané nganggo gawané gending, tabuhan kenong yo kudu goyang, jalaran antarané kendhangan karo kenongané wis nyawiji ora pisah, loro-loroné dadi jati diriné Ladrang Sobrang (Wawancara, 12 April 2017 di Keraton Surakarta).

[Ladrang Sobrang sléndro nem, jika menggunakan kendangan gawan gending, maka tabuhan kenong harus kenong goyang, karena antara kendangan dengan kenong goyang telah menyatu, keduanya tidak dapat dipisahkan dan telah menjadi jati diri dari Ladrang Sobrang.]

Pernyataan seperti tersebut di atas, berbeda dengan penjelasan K.R.T Radyo Adi Nagoro sebagai berikut.

Asliné sing duwé kendhangan pamijen lan kenong goyang kuwi Ladrang Sobrang laras pélog patêt barang, amargo ana hubungane karo gêrak tari, dadi nék Sobrang sléndro nèm nganggo kendhangan pamijen lan kênong goyang kuwi, nyilih saka Sobrang pélog (Wawancara, 12 Juni 2017 di Keraton Surakarta).

[Ladrang Sobrang yang mempunyai kendangan pamijen dan kenong goyang aslinya Sobrang laras pelog patet barang, karena ada hubungannya dengan gerak tari, jika kemudian Sobrang slendro menggunakan kendangan pamijen dan kenong goyang itu artinya meminjam dari Sobrang pelog]

Kenong goyang itu bahkan secara tradisi juga digunakan untuk Ladrang Surung dayung laras pelog patet nem, dugaan penulis mengapa kenong goyang juga digunakan untuk ladrang itu, karena Ladrang Surung dayung juga terdapat susunan balungan yang sama dengan Ladrang Sobrang. Kenong goyang pada Ladrang Sobrang terdapat pada cengkok atau gong-an ketiga kenong kedua dan kenong ketiga. Berikut adalah letak tabuhan kenong goyang.

$$
\begin{aligned}
& \text { - } 561232 \\
& \text {. } 216 \quad 5612
\end{aligned}
$$




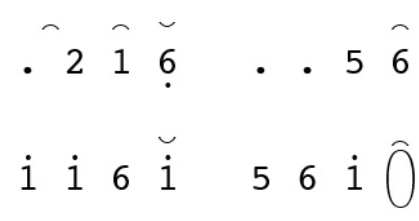

Keterangan: $\quad$ : kenong; : kempul; : : gong

\section{Penutup}

Berdasarkan analisis padhang-ulihan diketahui bahwa kalimat lagu Ladrang Sobrang yang terdiri dari empat cengkok antara cengkok satu dengan cengkok yang lain mempunyai korelasi yang sangat erat, cengkok A merupakan kalimat lagu padhang cengkok B. Cengkok B merupakan kalimat lagu padhang cengkok $\mathrm{C}$, dan cengkok $\mathrm{C}$ merupakan kalimat lagu padhang cengkok D, serta cengkok D merupakan kalimat lagu ulihan. Dengan demikian susunan padhang-ulihan-nya adalah P- P- P- U.

Analisa patet, baik berdasarkan nada tonika, séléh gong maupun garap, diketahui cengkok A terdiri dari dua patet sanga dan manyura. Cengkok $\mathrm{B}$ patet sanga utuh, cengkok $\mathrm{C}$ patet sanga utuh, tetapi pada kenong keempat ada kemungkinan digarap patet manyura, sehingga cengkok $\mathrm{C}$ merupakan campuran patet sanga dan manyura. Selanjutnya pada cengkok D kenong pertama, kedua dan ketiga patet manyura, kenong keempat patet nem.

Akhirnya dapat disimpulkan, bahwa Ladrang Sobrang adalah salah satu gending berbentuk ladrang yang cukup rumit dan sulit. Rumit dan sulit itu karena terdiri dari dua patet yaitu patet sanga dan manyura, mempunyai kendangan tersendiri (pamijen), dan mempunyai pola tabuhan kenong yang lazim disebut kenongan goyang. Ladrang Sobrang walaupun termasuk gending yang sangat populer tetapi jarang disajikan, oleh karena itu maka intensitas penyajian pada klenengan sangat rendah atau sedikit.

\section{Kepustakaan}

Budi Prasetya, H., Haryono, T., \& Simatupang, L. L. (2011). Habitus, Ngêng, dan Estetika Bunyi Mlèsèt dan Nggandhul Pada Karawitan. Paradigma, Jurnal Kajian Budaya, 1(2), 152 167.
Diah K, F. X. (2010). Gending-gending lringan Upacara Perkawinan Agung di Keraton Yogyakarta. Ornamen, 7(2), 59-70.

Djumadi. (1975). Titilaras Rebaban Jilid I. Akademi Seni Karawitan Indonesia, Surakarta.

Finahari, N., \& Soebiyakto, G. (2017). Analisis Numerik Karakteristik Intensitas Suara Gending Jawa. Dinamika Teknik Mesin, 7(1), 7-21.

Martopangrawit, R. 1. (1975). Pengetahuan Karawitan Jilid I. Surakarta: Akademi Seni Karawitan Indonesia.

Mloyowidodo. (1973). Balungan Gending Jilid I, II, III,. Surakarta: Bagian Reserch Konservatori Karawitan Indonesia

Osada, S. S. (2015). Etnomatematika dalam Titi Laras dan Irama Pada Karawitan Jawa. In Prosiding Seminar Nasional Etnomatnesia, Universitas Sanata Dharma Yogyakarta (pp. 475-481).

Prajapangrawit, R. N. (1990). Serat Sujarah Utawi Riwayating Gamelan Wedhapradangga. STSI Surakarta dengan Fort Foundation, Surakarta.

Prasetya, H. B. (2012). Pathêt: Ruang Bunyi dalam Karawitan Gaya Yogyakarta. Panggung Jurnal Seni Dan Budaya, 22(3), 67-82.

Prasetya, H. B. (2013). Mlesed dan Nggandhul dalam Karawitan Pedalangan Gaya Yogyakarta. Yogyakarta: Universitas Gadjah Mada Yogyakarta.

Purwanto, D. (2013). Permainan Ricikan Kenong dalam Karawitan Jawa Gaya Surakarta. Gelar Jurnal Seni Budaya, 11(2), 121-138.

Saepudin, A. (2012). Praktik Karawitan Daerah Lain I Karawitan Sunda. Diktat Jurusan Karawitan FSP ISI Yogyakarta.

Saepudin, A. (2015a). Laras, Surupan, dan Patet dalam Praktik Menabuh Gamelan Salendro. Resital Jurnal Seni Pertunjukan, 16(1), 52-64. https://doi.org/http://dx.doi.org/10.24821/ resital.v16i1.1274

Saepudin, A. (2015b). Metode Pembelajaran Tepak Kendang Jaipongan (1st ed.). Yogyakarta: Badan Penerbit ISI Yogyakarta.

Setiawan, S. (2015). Konsep Kendangan Pematut Karawitan Jawa Gaya Surakarta. Tesis S2 Program Studi Penciptaan dan Pengkajian 
Seni Minat Studi Pengkajian Musik Nusantara ISI Surakarta.

Setyawan, A. D. (2017). Karawitan Jawa Sebagai Media Belajar dan Media Komunikasi Sosial. Trihayu: Jurnal Pendidikan Ke-SD-An, 3(2), 78-82.

Sri Atmojo, B. (2010). Kendhangan Pamijen Gending Gaya Yogyakarta. Resital Jurnal Seni Pertunjukan, 11(1), 45-58.

Sugimin. (2013). Aneka Garap Ladrang Pangkur. Keteg, 13(1), 88-122.

Sukistono, D. (2014). Pengaruh Karawitan terhadap Totalitas Ekspresi Dalang dalam Pertunjukan Wayang Golek Menak Yogyakarta. Resital: Jurnal Seni Pertunjukan, 15(2), 179-189.

Suwandi Putri, Fikroturrofiah \& Ardhi Saputri, A. (2015). Rebab Instrumen Gesek Gamelan: Analisis Hubungan Antara Posisi Gesekan dan Komponen Penyusun Sinyal Suara (pp. 16-20). Seminar Nasional Fisika dan
Pembelajarannya di Universitas Negeri Yogyakarta

Widodo, Ganap, V. \& S. (2017). Laras Concept and Its Triggers: A Case Study on Garap of Jineman Uler Kambang. Harmonia: Journal of Arts Research and Education, 17(1), 7586. https://doi.org/10.15294/harmonia. v17i1.10771

\section{Informan}

R.R.A Saptodiningrat (Saptono). Umur 67 tahun, Pengendang dan pengrebab, abdi dalem pengrawit Keraton Kasunanan Surakarta.

K.R.A.T Broto Adi Nagoro (Djumadi). Umur 78 tahun, pengrebab, abdi dalem pengrawit Keraton Kasunanan Surakarta.

K.R.T. Radyo Adi Nagoro (Suwito). Umur 60 tahun, Pengendang, pengrebab abdi dalem pengrawit Keraton Kasunanan Surakarta. 